PREPARED FOR THE U.S. DEPARTMENT OF ENERGY, UNDER CONTRACT DE-AC02-76CH03073

PPPL-3713

PPPL-3713

UC-70

\title{
Multiple Electron Stripping \\ of Heavy Ion Beams
}

by

D. Mueller, L. Grisham, I. Kaganovich, R.L. Watson,

V. Horvat, K.E. Zaharakis, and Y. Peng

June 2002

NM|

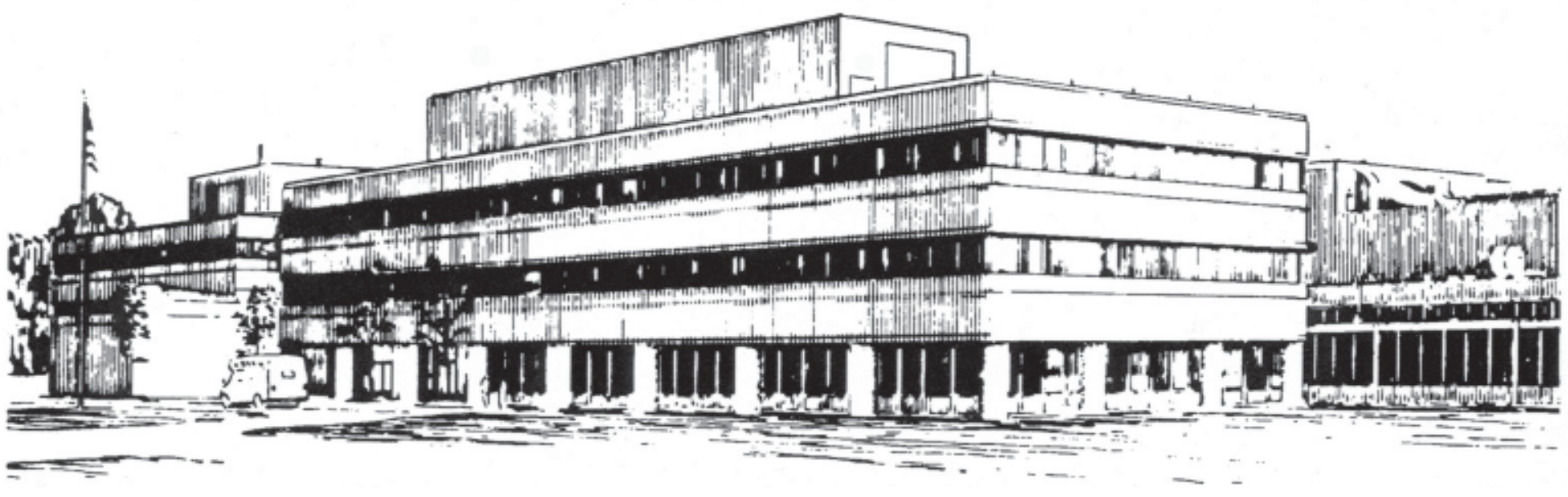

PRINCETON PLASMA PHYSICS LABORATORY PRINCETON UNIVERSITY, PRINCETON, NEW JERSEY 


\section{PPPL Reports Disclaimer}

This report was prepared as an account of work sponsored by an agency of the United States Government. Neither the United States Government nor any agency thereof, nor any of their employees, makes any warranty, express or implied, or assumes any legal liability or responsibility for the accuracy, completeness, or usefulness of any information, apparatus, product, or process disclosed, or represents that its use would not infringe privately owned rights. Reference herein to any specific commercial product, process, or service by trade name, trademark, manufacturer, or otherwise, does not necessarily constitute or imply its endorsement, recommendation, or favoring by the United States Government or any agency thereof. The views and opinions of authors expressed herein do not necessarily state or reflect those of the United States Government or any agency thereof.

\section{Availability}

This report is posted on the U.S. Department of Energy's Princeton Plasma Physics Laboratory Publications and Reports web site in Fiscal Year 2002. The home page for PPPL Reports and Publications is: http://www.pppl.gov/pub_report/

DOE and DOE Contractors can obtain copies of this report from:

U.S. Department of Energy

Office of Scientific and Technical Information

DOE Technical Information Services (DTIS)

P.O. Box 62

Oak Ridge, TN 37831

Telephone: (865) 576-8401

Fax: (865) 576-5728

Email: reports@adonis.osti.gov

This report is available to the general public from:

National Technical Information Service

U.S. Department of Commerce

5285 Port Royal Road

Springfield, VA 22161

Telephone: 1-800-553-6847 or

(703) 605-6000

Fax: (703) 321-8547

Internet: http://www.ntis.gov/ordering.htm 


\title{
Multiple Electron Stripping of Heavy Ion Beams
}

\author{
D. Mueller, L. Grisham and I. Kaganovich \\ Princeton University Plasma Physics Laboratory, Princeton University, P.O. Box 451, \\ Princeton, New Jersey, 08543, USA \\ R. L. Watson, V. Horvat, K. E. Zaharakis, and Y. Peng \\ Cyclotron Institute, Texas A\&M University, College Station, Texas, 77843, USA
}

\begin{abstract}
One approach being explored as a route to practical fusion energy uses heavy ion beams focused on an indirect drive target. Such beams will lose electrons while passing through background gas in the target chamber, and therefore it is necessary to assess the rate at which the charge state of the incident beam evolves on the way to the target. Accelerators designed primarily for nuclear physics or high energy physics experiments utilize ion sources that generate highly stripped ions in order to achieve high energies economically. As a result, accelerators capable of producing heavy ion beams of 10 to 40 Mev/amu with charge state 1 currently do not exist. Hence, the stripping cross-sections used to model the performance of heavy ion fusion driver beams have, up to now, been based upon theoretical calculations. We have investigated experimentally the stripping of 3.4 Mev/amu $\mathrm{Kr} 7+$ and $\mathrm{Xe}{ }^{+11}$ in $\mathrm{N}_{2} ; 10.2 \mathrm{MeV} / \mathrm{amu} \mathrm{Ar}^{+6}$ in $\mathrm{He}, \mathrm{N}_{2}, \mathrm{Ar}$ and Xe; $19 \mathrm{MeV} / \mathrm{amu} \mathrm{Ar}^{+8}$ in $\mathrm{He}, \mathrm{N}_{2}, \mathrm{Ar}$ and $\mathrm{Xe} ; 30 \mathrm{MeV} \mathrm{He}$ 1+ in $\mathrm{He}, \mathrm{N}_{2}, \mathrm{Ar}$ and $\mathrm{Xe}$; and $38 \mathrm{MeV} / \mathrm{amu} \mathrm{N}^{+6}$ in $\mathrm{He}, \mathrm{N}_{2}, \mathrm{Ar}$ and $\mathrm{Xe}$. The results of these measurements are compared with the theoretical calculations to assess their applicability over a wide range of parameters.
\end{abstract}

\section{INTRODUCTON}

Use of energetic heavy ion beams as a driver for inertial confinement fusion is a technique that is under development. The heavy ion beam focused on an indirect drive target would produce x-rays, which then compress the deuterium-tritium target. (Bangerter, 1996) The target chamber gas in one reference design, HYLIFE-II, would probably be comprised of vapor from FLIBE, a salt of fluorine, lithium and 
beryllium. The gas density of beryllium difluoride in this design is expected to be $5 \times 10^{13} \mathrm{~cm}^{-3}$. (Callahan 1996) As the heavy ion beam propagates through this background gas, it would undergo electron stripping reactions that would raise the space-charge density of the beam. This can cause the beam spot to expand, reducing the power density on the target. Ionization of the background gas would supply space-charge-neutralizing electrons, which could compensate for the space-charge defocusing force on the positive ion beam. It is important to have accurate cross sections for electron stripping cross sections of the heavy ion beams in order to estimate these effects on the transport of the beam through the chamber to the target. In a previous experiment using $\mathrm{Kr} 7+$ and $\mathrm{Xe}^{+11}$ beams at 3.4 $\mathrm{MeV} / \mathrm{amu}$, the first experimental demonstration that such energetic ions undergo multiple electron stripping events in a background gas of $\mathrm{N}_{2}$ was made.( Mueller et al. 2001) As a result, the charge state of the ion beam increases more rapidly than would be the case if only a single electron were lost in each encounter. This effect must be included in the transport calculations of heavy ion beams. Unfortunately, there are currently no accelerators capable of accelerating heavy ions (A 200) with charge state 1 to the energy range envisioned (20 to $40 \mathrm{MeV} / \mathrm{amu}$ ) so the electron stripping cross sections cannot be measured directly by experiment and must be obtained from theoretical calculations. We have performed additional measurements, which along with those made by Olson, et al. (2002), provide experimental data for comparison with theory over a range of beam energy, beam species, and gas target species. Agreement of calculations with the measurements would provide a measure of confidence that the theory might be applicable in a regime that is not yet experimentally available.

\section{EXPERIMENT}

Beams of and 10.2 MeV/amu $\mathrm{Ar}^{+6}, 19 \mathrm{MeV} / \mathrm{amu} \mathrm{Ar}{ }^{+8}, 30 \mathrm{Mev} / \mathrm{amu} \mathrm{He}{ }^{+1}$ and $38 \mathrm{MeV} / \mathrm{amu} \mathrm{N}$ ${ }^{+6}$ were extracted from the Texas A\&M K500 superconducting cyclotron. The beams were directed 
through a 22 degree deflection magnet located $10 \mathrm{~m}$ in front of the target chamber. The beam was collimated by three 1-mm diameter apertures followed by a 2-mm diameter collimator before entering a differentially-pumped gas cell. The number of collimators was reduced for the most energetic beams because the range of the beams was greater than the collimator's thickness, and the extra collimators resulted in a large low energy tail on the beam distribution. The gas cell of effective length $0.0208 \mathrm{~m}$ was filled with gas ( $\mathrm{He}, \mathrm{N}_{2}, \mathrm{Ar}$ or $\left.\mathrm{Xe}\right)$ to pressures from 1 to 250 mTorr, as measured by a capacitance manometer, and maintained by an automatic fill valve to about \pm 0.3 mTorr accuracy. The background pressure in the beam line and target chamber were monitored with ion gauges and ranged between 1.5 and $5.0 \times 10^{-6}$ Torr, depending on target cell pressure and vacuum history. After exiting the gas cell, the beam passed between the poles of another magnet to disperse the charge states and on to a position-sensitive microchannel plate detector (PSD). Data was also taken with no flow in the gas cell to assess the stripping of the beam in the background gas and scattering from beam collimators. In order to avoid rate-dependent gain changes and extraneous peaks due to pulse pile-up, the counting rate was kept below 1500 counts/s. The charge distributions were measured until the statistical uncertainties of the number of counts in the peaks representing less than 4-electron loss were better than $2 \%$.

\section{RESULTS}

Tables 1 through 3 list the cross sections for electron stripping of the incident beams in the various target gases. The statistical uncertainty is listed in the tables for each case. There is also an estimated error of about $20 \%$ for cross sections below $10^{-18} \mathrm{~cm}^{2}$ and $10 \%$ for cross sections above that, due to differences in assessing the background for each of the peaks in the measured beam charge distribution and in the effective length of the target cell. It is clear that the average number of electrons lost per encounter increases with increasing target atomic number. This effect is most pronounced for $19 \mathrm{MeV}$ 
$\mathrm{Ar}^{+8}$ where the average charge change per encounter rises from 1.16 for He to 2.01 for Xe. The weighted cross sections shown in Table 3 are the cross sections weighted by the number of electrons lost in the encounter. Figures 1 and 2 show the cross section versus number of electrons lost in the various gases by $10.2 \mathrm{MeV} / \mathrm{amu} \mathrm{Ar}^{+6}$ and $19 \mathrm{MeV} / \mathrm{amu} \mathrm{Ar}^{+8}$, respectively. The weighted cross sections for all of the beams we have used so far are summarized in Figure 3 as a function of target atomic number. The cross sections increase with increasing target $\mathrm{Z}$ and decrease with increasing beam energy in a broad energy and beam species range.

The cross sections, labeled "Born" and "classical" in Table 3, are the results of calculations described by Kaganovich, et al. (2001). The Born approximation, which results in overestimate of the cross sections, should be valid for $Z_{T} e^{2}<<\mathrm{h} V$, where $Z_{T}$ is the target atomic number and $V$ is the velocity of the beam ion relative to the target atom. The classical trajectory calculations do not account for tunneling transitions allowed by quantum mechanics. Neither approach is expected to perform well across a wide spectrum of beams and targets. Aspects of one must be included in the other in order to address shortcomings in the underlying assumptions. In the calculations for argon, we used simplistic assumptions based on one-electron ion scaling and ionization potential for the electron distribution function. Therefore, as expected, agreement with experiment is not as good for Ar as it is for N+6, where these functions are exact. More accurate calculations that account for the exact orbital electron distribution functions and ionization probabilities will be performed in the near future.

The approximation used neglects the larger ionization potential for removal of multiple electrons. This leads to an overestimate in the calculation, especially for the case of $\mathrm{Xe}$, where multiple electron events are more important. Table 3, which includes the total weighted cross sections for each gas and the three beam ion species used in this experiment, shows that both approximations give good estimates, except for the Xe case. The good agreement with experiment for the classical calculation suggests that tunneling transitions do not provide a major contribution to the cross section. This is not 
expected to be the case for ionized targets and/or low ionization potentials of the projectile, (see, for example, He data in Table 3), where classical calculations would strongly underestimate the cross section. (Kaganovich et al. 2002) New experiments are needed to further check these theoretical predictions.

\section{CONCLUSIONS}

We have measured the electron stripping cross sections for a variety ion beam energies and species using different target gases. Together with the Xe data data of Olson et al. (2002), this provides a broad range over which to test the theoretical calculations of the electron stripping of proposed heavy ion drivers for inertial confinement fusion by background gas in the target chamber.

\section{ACKNOWLEDGEMENTS}

We gratefully acknowledge the staff at the Texas A\&M Cyclotron Institute, especially Don May and George Kim, who proved invaluable in providing the desired ion beam species. This research supported by US. DOE Contract No. DE-AC0276CH03073 and the Robert A. Welch Foundation. 
Table 1. The measured cross-sections per atom for electron stripping of $10.2 \mathrm{MeV} / \mathrm{amu} \mathrm{Ar}^{+6}$ in various gases in units of $10^{-18} \mathrm{~cm}^{2}$.

\begin{tabular}{|c|r|r|r|r|r|}
\hline Target gas & \multicolumn{1}{|c|}{$1 \mathrm{e}$} & \multicolumn{1}{c|}{$2 \mathrm{e}$} & \multicolumn{1}{c|}{$3 \mathrm{e}$} & \multicolumn{1}{c|}{$4 \mathrm{e}$} & \multicolumn{1}{c|}{$5 \mathrm{e}$} \\
\hline $\mathrm{He}$ & $2.18 \pm 0.09$ & $1.65 \pm 0.05$ & $0.044 \pm 0.02$ & & \\
\hline $\mathrm{N}_{2}$ & $10.77 \pm 0.05$ & $8.96 \pm 0.03$ & $1.10 \pm 0.01$ & $0.221 \pm 0.006$ & $0.047 \pm 0.003$ \\
\hline $\mathrm{Ar}$ & $27.4 \pm 0.2$ & $19.5 \pm 0.1$ & $6.17 \pm 0.08$ & $2.64 \pm 0.04$ & $1.02 \pm 0.03$ \\
\hline $\mathrm{Xe}$ & $50.1 \pm 0.5$ & $33.1 \pm 0.3$ & $13.4 \pm 0.2$ & $7.8 \pm 0.1$ & $5.6 \pm 0.1$ \\
\hline
\end{tabular}


Table 2. The measured cross-sections per atom for electron stripping of $19 \mathrm{MeV} / \mathrm{amu} \mathrm{Ar}^{+8}$ in various gases in units of $10^{-18} \mathrm{~cm}^{2}$.

\begin{tabular}{|c|r|c|c|c|c|}
\hline Target gas & \multicolumn{1}{|c|}{$1 \mathrm{e}$} & \multicolumn{1}{c|}{$2 \mathrm{e}$} & \multicolumn{1}{c|}{$3 \mathrm{e}$} & \multicolumn{1}{c|}{$4 \mathrm{e}$} & \multicolumn{1}{c|}{$5 \mathrm{e}$} \\
\hline $\mathrm{He}$ & $1.2 \pm 0.1$ & $0.12 \pm 0.01$ & $0.05 \pm 0.01$ & & \\
\hline $\mathrm{N}_{2}$ & $6.33 \pm 0.04$ & $0.57 \pm 0.01$ & $0.10 \pm 0.01$ & $0.030 \pm 0.003$ & $0.02 \pm 0.01$ \\
\hline $\mathrm{Ar}$ & $16.3 \pm 0.1$ & $4.29 \pm 0.05$ & $1.50 \pm 0.03$ & $0.59 \pm 0.02$ & $0.27 \pm 0.02$ \\
\hline $\mathrm{Xe}$ & $22.8 \pm 0.2$ & $9.86 \pm 0.07$ & $5.53 \pm 0.04$ & $3.12 \pm 0.03$ & $1.82 \pm 0.02$ \\
\hline
\end{tabular}


Table 3. The total electron-loss weighted cross-sections per atom compared with the calculated cross sections in units of $10^{-18} \mathrm{~cm}^{2}$.

\begin{tabular}{|c|c|c|c|c|c|c|}
\hline & \multicolumn{3}{|c|}{ 10.2 $\mathrm{MeV} / \mathrm{amu} \mathrm{Ar}{ }^{+6}$} & \multicolumn{3}{|c|}{$19 \mathrm{MeV} / \mathrm{amu} \mathrm{Ar}^{+8}$} \\
\hline Target gas & Experiment & Born & Classical & Experiment & Born & Classical \\
\hline $\mathrm{He}$ & $5.61 \pm 0.23$ & 3.13 & 4.23 & $1.59 \pm 0.14$ & 1.00 & 1.13 \\
\hline $\mathrm{N}_{2}$ & $33.4 \pm 0.2$ & 23.8 & 30.7 & $8.04 \pm 0.09$ & 7.73 & 9.55 \\
\hline $\mathrm{Ar}$ & $100.5 \pm 0.4$ & 104 & 106 & $34.4 \pm 0.4$ & 36.4 & 40.3 \\
\hline \multirow[t]{2}{*}{$\mathrm{Xe}$} & $215 \pm 3$ & 633 & 358 & $89.4 \pm 0.8$ & 234 & 157 \\
\hline & \multicolumn{3}{|c|}{$30 \mathrm{MeV} / \mathrm{amu} \mathrm{He}{ }^{+1}$} & \multicolumn{3}{|c|}{$38 \mathrm{MeV} / \mathrm{amu} \mathrm{N}^{+6}$} \\
\hline Target gas & Experiment & Born & Classical & Experiment & Born & Classical \\
\hline $\mathrm{He}$ & $0.49 \pm 0.07$ & 0.30 & 0.69 & $0.06 \pm 0.01$ & 0.044 & 0.046 \\
\hline $\mathrm{N}_{2}$ & $1.92 \pm 0.10$ & 2.4 & 4.1 & $0.34 \pm 0.04$ & 0.34 & 0.36 \\
\hline $\mathrm{Ar}$ & $7.3 \pm 0.4$ & 9.0 & 11.5 & $1.64 \pm 0.03$ & 1.58 & 1.58 \\
\hline $\mathrm{Xe}$ & $23 . \pm 1$ & 47 & 36 & $6.29 \pm 0.04$ & 10.30 & 6.50 \\
\hline
\end{tabular}




\section{REFERENCES}

Bangerter, R. O. 1996 J. Fusion Engineering and Design 15-16, 27.

Callahan, D. A. 1996 J. Fusion Engineering and Design 15-16, 441.

Kaganovich, I. D., Startsev, E. \& Davidson, R. C. 2001 "Evaluation of Ionization Cross-Sections in

Energetic Ion-Atom Collisions," Proceedings of the 2001 Particle Accelerator Conference, pp. 16491651 to be submitted to Phys. Rev.A., and preprint available at http://accelconf.web.cern.ch/AccelConf/p01/PAPERS/TPAH314.PDF .

Mueller, D., Grisham, L., Kaganovich, I., Watson, R. L., Horvat, V, Zaharakis, K.E. \& Armel. M. S. 2001 Phys. Plasmas 8, 1753.

Olson, R. E., Watson, R. L., Horvat, V \& Zaharakis, K.E. 2002 J. Phys. B: 35, 1893.

\section{FIGURE CAPTIONS}

Figure 1. Cross section per atom versus number of electrons lost in $\mathrm{He}, \mathrm{N}_{2}, \mathrm{Ar}$ and $\mathrm{Xe}$ by a 10.2 $\mathrm{MeV} / \mathrm{amu} \mathrm{Ar}^{+6}$ beam.

Figure 2. Cross section per atom versus number of electrons lost in $\mathrm{He}, \mathrm{N}_{2}, \mathrm{Ar}$ and $\mathrm{Xe}$ by a 19 $\mathrm{MeV} / \mathrm{amu} \mathrm{Ar}^{+8}$ beam.

Figure 3. Weighted cross section per atom versus atomic number of the target gas for the various beams used. 


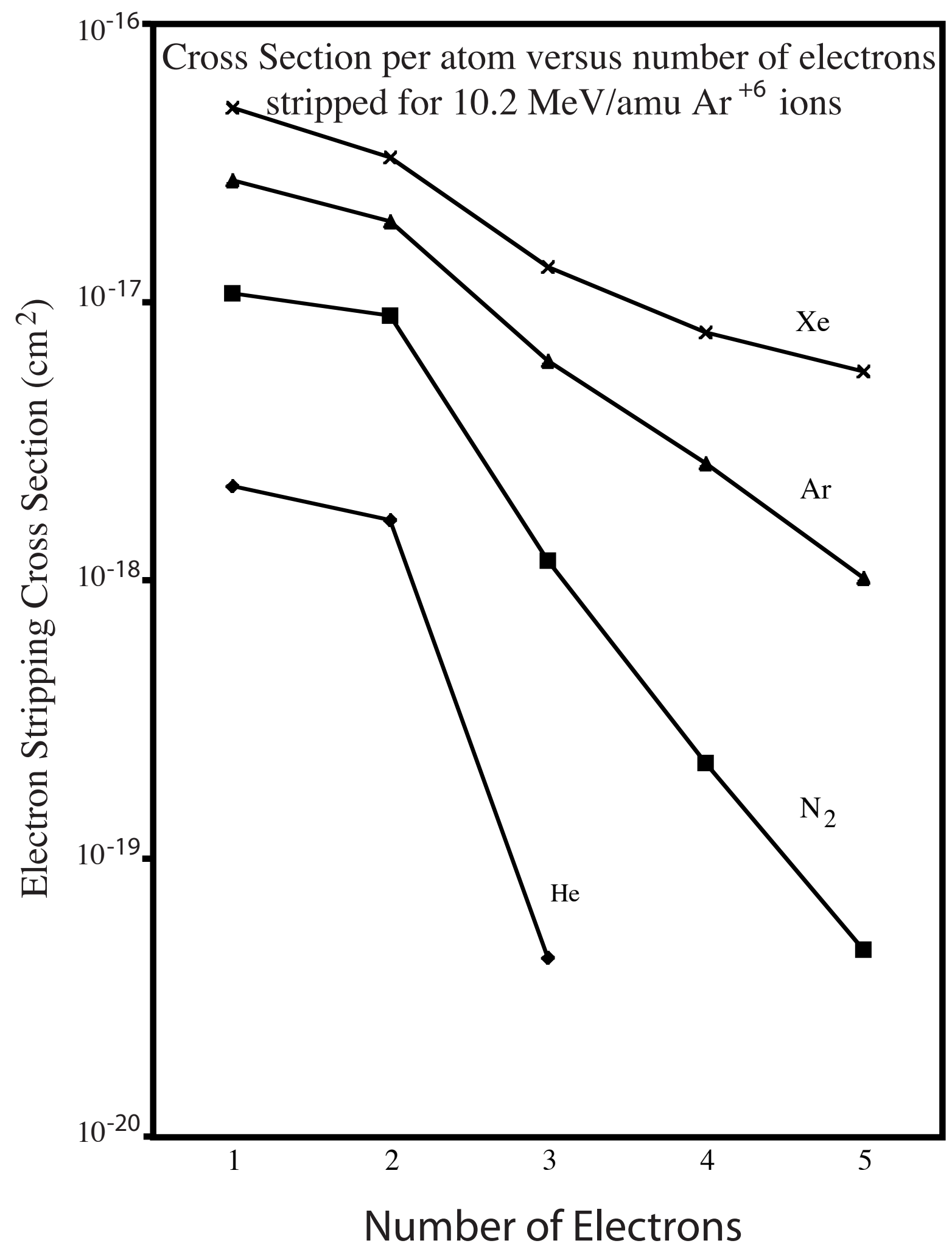




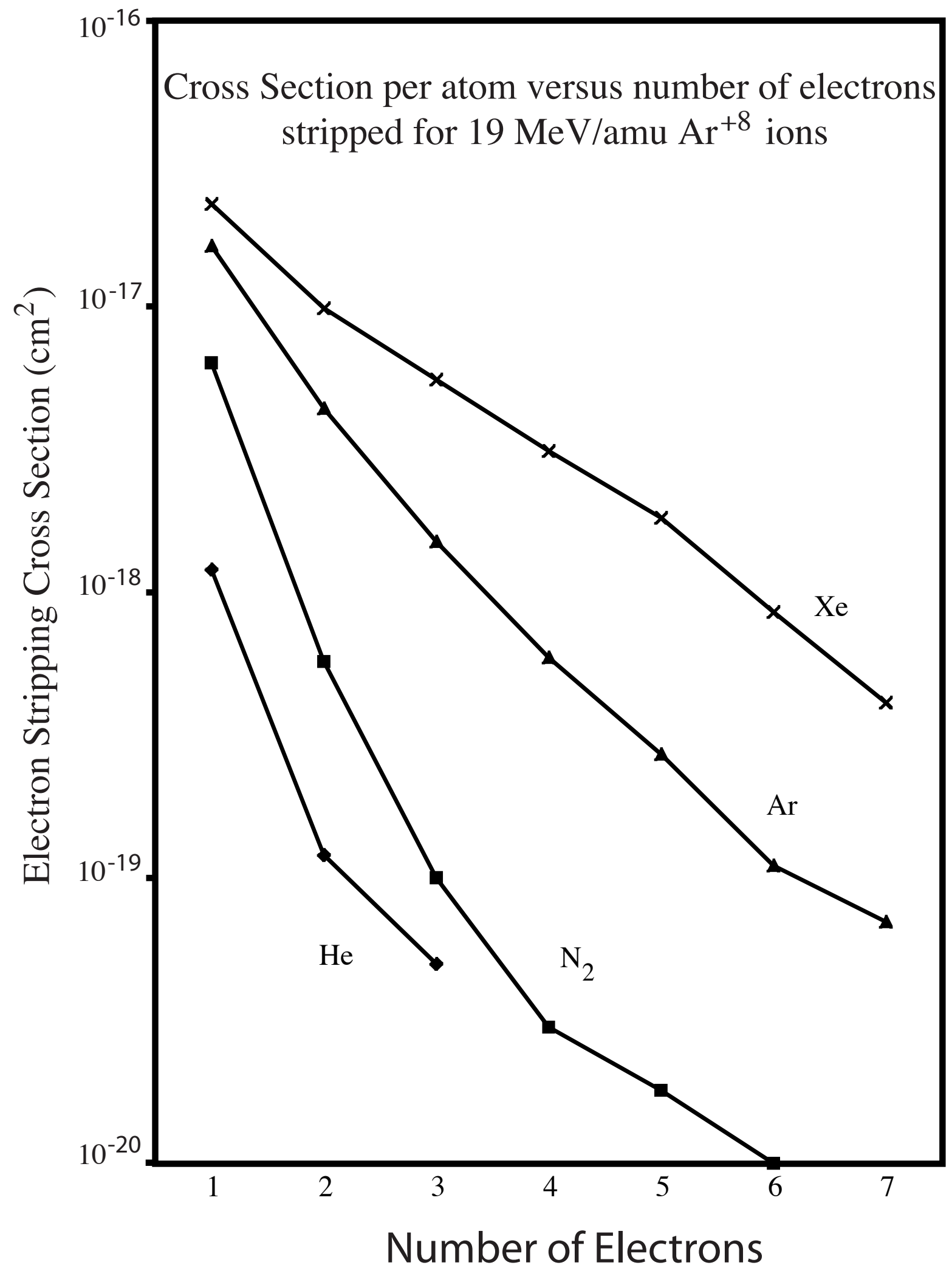




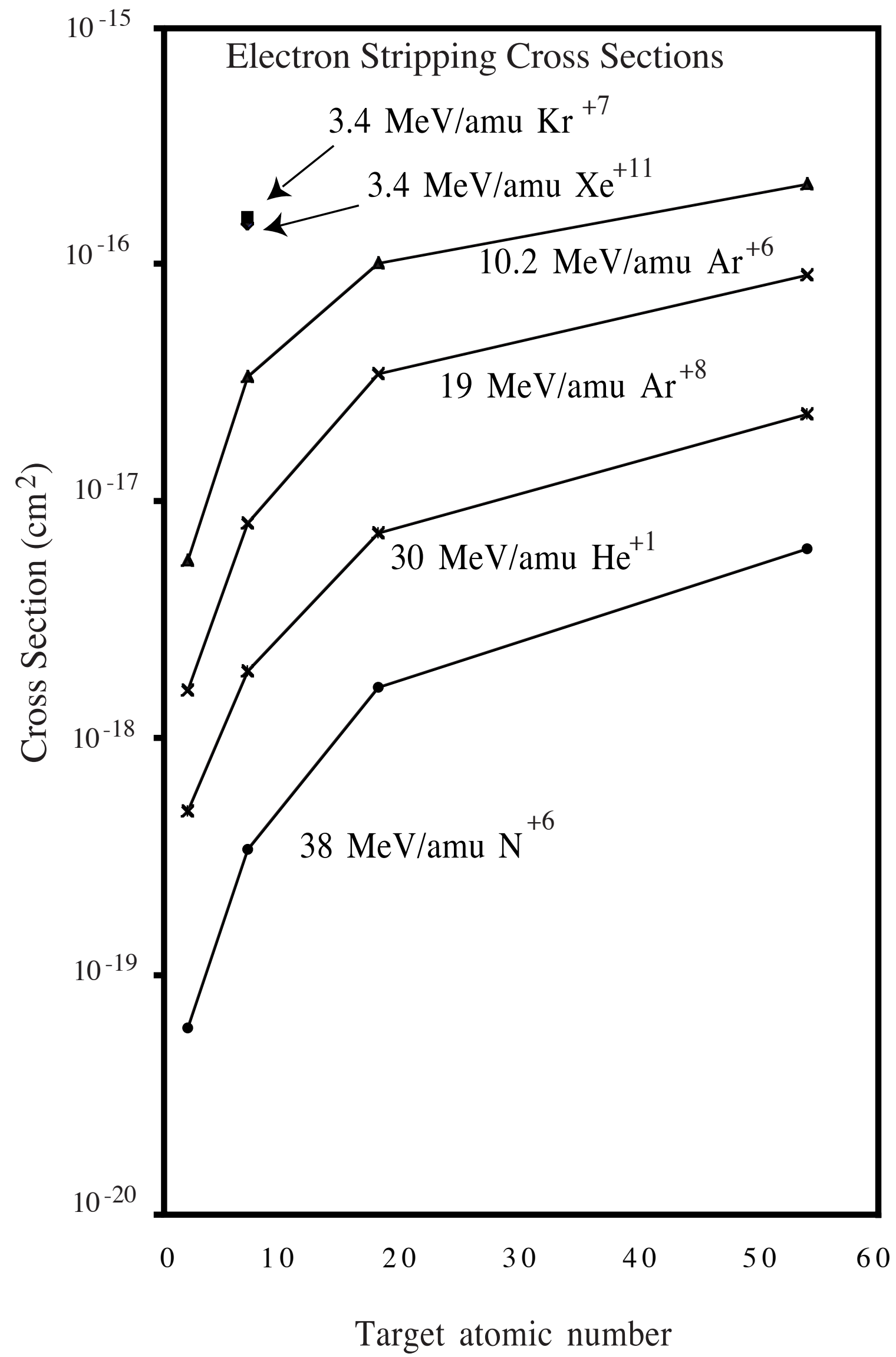




\section{External Distribution}

Plasma Research Laboratory, Australian National University, Australia

Professor I.R. J ones, Flinders University, Australia

Professor J oão Canalle, Instituto de Fisica DEQ/IF - UERJ , Brazil

Mr. Gerson O. Ludwig, Instituto Nacional de Pesquisas, Brazil

Dr. P.H. Sakanaka, Instituto Fisica, Brazil

The Librarian, Culham Laboratory, England

Library, R61, Rutherford Appleton Laboratory, England

Mrs. S.A. Hutchinson, JET Library, England

Professor M.N. Bussac, Ecole Polytechnique, France

Librarian, Max-Planck-Institut für Plasmaphysik, Germany

J olan Moldvai, Reports Library, MTA KFKI-ATKI, Hungary

Dr. P. Kaw, Institute for Plasma Research, India

Ms. P.J . Pathak, Librarian, Insitute for Plasma Research, India

Ms. Clelia De Palo, Associazione EURATOM-ENEA, I taly

Dr. G. Grosso, Instituto di Fisica del Plasma, Italy

Librarian, Naka Fusion Research Establishment, J AERI, J apan

Library, Plasma Physics Laboratory, Kyoto University, J apan

Research Information Center, National Institute for Fusion Science, J apan

Dr. O. Mitarai, Kyushu Tokai University, J apan

Library, Academia Sinica, Institute of Plasma Physics, People's Republic of China

Shih-Tung Tsai, Institute of Physics, Chinese Academy of Sciences, People's Republic of China

Dr. S. Mirnov, TRINITI, Troitsk, Russian Federation, Russia

Dr. V.S. Strelkov, Kurchatov Institute, Russian Federation, Russia

Professor Peter Lukac, Katedra Fyziky Plazmy MFF UK, Mlynska dolina F-2, Komenskeho Univerzita, SK-842 15 Bratislava, Slovakia

Dr. G.S. Lee, Korea Basic Science Institute, South Korea

Mr. Dennis Bruggink, Fusion Library, University of Wisconsin, USA

Institute for Plasma Research, University of Maryland, USA

Librarian, Fusion Energy Division, Oak Ridge National Laboratory, USA

Librarian, Institute of Fusion Studies, University of Texas, USA

Librarian, Magnetic Fusion Program, Lawrence Livermore National Laboratory, USA

Library, General Atomics, USA

Plasma Physics Group, Fusion Energy Research Program, University of California at San Diego, USA

Plasma Physics Library, Columbia University, USA

Alkesh Punjabi, Center for Fusion Research and Training, Hampton University, USA

Dr. W.M. Stacey, Fusion Research Center, Georgia Institute of Technology, USA

Dr. J ohn Willis, U.S. Department of Energy, Office of Fusion Energy Sciences, USA

Mr. Paul H. Wright, Indianapolis, Indiana, USA 
The Princeton Plasma Physics Laboratory is operated by Princeton University under contract with the U.S. Department of Energy.

\author{
Information Services \\ Princeton Plasma Physics Laboratory \\ P.O. Box 451 \\ Princeton, NJ 08543
}

Phone: 609-243-2750

Fax: 609-243-2751

e-mail: pppl_info@pppl.gov

Internet Address: http://www.pppl.gov 